\title{
ON DELIMITING AFRICAN PHILOSOPHY AND THE EQUALIZATION SCHEME
}

\author{
Emmanuel J. Ibuot \\ doi: http://dx.doi.org/10.4314/og.v8i1.11
}

\begin{abstract}
The discourse on the meaningfulness of Africans has taken various dimensions over the decades, especially as it has to do with asserting that Africans had her civilizations, and so were inherently dignified people. One of these dimensions is African Philosophy where lots of African scholars have invested their time and mind on examining the African universe and bringing forth various descriptions of the African life. And in line with this, some schools of thought in African Philosophy have developed. It seems to me that these schools may not be thorough and principle-based; they appear to have been fuelled by sentiments and ego-protection principle. How valid and sound are these schools of thoughts? Do these schools exhaust all there is to African Philosophy in the present? In this paper, the researcher thinks that the various schools of African Philosophy were not well-founded, and that there still exists another school of thought deducible from the various contributions of contemporary scholars in African thought; it also demonstrates that even this school of thought is an exercise in contradiction to the aspirations of these scholars in particular and of Africans in general.
\end{abstract}

\section{Introduction}

African Philosophy as a movement in asserting and affirming the identity and dignity of Africans, who felt insulted, scorned, and crushed by occidental worldviews and ideologies. While there are all kinds of claims as regards its origin, some of them include; 1) the work of Placide Tempels, Bantu Philosophy, 2) the PhD work of Theophilus Okere in 1971 on "African Philosophy: A HistoricoHermeneutical Investigation of the Conditions of its Possibility" - an extract was published in $1983^{1}$; 3) the claim of T. U. Nwala of being the trailblazer of the teaching of African Philosophy as a course at 
the University of Nigeria in 1972 that is said to have triggered off interests for the course in other universities worldwide ${ }^{2}$; and 4) the Great Debate that started as a result of an article in the Second Order in 1972.

Defining African philosophy seems to be intricately bound up with an understanding the Great Debate. When the Second Order, An African Journal of Philosophy began in 1972 at the Obafemi Awolowo University, Ile-Ife, the intention of its editor, John Sodipo, was the examination of the structural nature of 'traditional African thought'. This concern was later seen in its full manifestation, though, as some argue, not inevitably, as the 'Great Debate'. The direction started off with a significant question by Mr. W.A. Hart:

The question is whether African thought as it exists in Africa is the same sort of thing with thought as understood by the Western philosopher and we Europeans or educated Africans who share his culture. $^{3}$

The above riddle by Mr. Hart was more or less a call for ethnographic studies of the thought-patterns of the Africans as against the Europeans. This can be easily deduced from another statement from Hart:

The development of ethnographical studies in recent years has aroused interest in the traditional thought of African peoples and has prompted the suggestion that there is something which the philosopher could study with profit. ${ }^{4}$

Evidently, this was not a calling into question the existence of African philosophy. Rather, it is an invitation into determining the uniqueness of the African mind, which to my mind, is a veritable and mentally attractive target. If there was nothing unique, then one could have seen its equalization with European thought. The 
reactions of the scholars became polarized between the existence and non-existence of African Philosophy. These opinions directly led to what may be described as the schools of thought in African philosophy. One may think that the digression by the African scholars towards the existence of African philosophy (apparently not intended by Hart) was unfounded. Nevertheless, there were many in the Western world, who believed that Africans have no philosophy David Hume, Georg Hegel, Karl Jaspers. So, when Mr. Hart invited research in comparative studies, little could it not be suspected as a subtle expression of doubt of the capability of the African in abstract thought by westerners. Within this setting, we may appreciate the different lines of response of scholars.

\section{The Various Trends in the Definition of African Philosophy}

In the arguments for the existence of African philosophy, its nature and scope, one inevitably discovers some trends of thoughts among the scholars. For this reason, some schools of thought have been discovered by C.S. Momoh, Henry Odera Oruka, T.U. Nwala. ${ }^{5}$ The various trends reveal that the ideas they defend revolve around certain presuppositions in regard to the definition of African philosophy. In other to examine these presuppositions, the writer would adopt a four-tier structure and query some of their ideas as it defines African philosophy. These structures will include ${ }^{6}$ Ethnology/Ethnophilosophy, Universalism, Hermeneutics, and Equalization Scheme.

\section{Ethnology/Ethnophilosophy}

This philosophy or mode of thought always involves the recording of the beliefs of the Africans. It is made up of a set of shared beliefs and shared worldviews. This thought-mode is the study, not of an individual's vision, but a communal property. Otherwise put, it is bent on revealing the picture of life in operation within an ethnolinguistic group. This ideology/ 'reason' - the 'logos' of the tribe may be found as encrypted in proverbs, folklores, customs, religion, traditional institutions/practices, etc. Ethnophilosophy may be 
considered as consisting of two main branches, namely: philosophic sagacity of the oralsophic philosophy and analytic traditionalists.

One major form of expression of ethnology/ethnophilosophy is Negritude that has Leopold Sedar Senghor and Aime Cesaire as its leading exponents. Negritude defines the African as characteristically emotion and in direct association with the skin colour. In approaching the reality of the world/life, the African followed his emotion, which makes for participation unlike logic (taken as defining the whites, i.e. the Europeans) that consists of distancing analyses. Thus, the Africans are tuned to the arts while the Europeans, to the sciences. Forerunners of Negritude will include: Alexander Crummel, Edward Blyden, D.E.B. Dubois and Alaine Locke. ${ }^{7}$

Another major expression of ethnology is Placide Tempels' Bantu Philosophy. Tempels followed the Saphir-Whorf thesis that was popular in the first half of the last century to argue that the categories of the language of the Bantu people reveal the metaphysical categories defining their view of reality. Fr. Alexis Kagame of Rwanda, towing this line, argued that the culture of every people is arranged around a set of principles, which are embedded in their language, beliefs/practices. The expression of which is not a determinant.

We find other expressions of this thought-form by Marcel Griaule, Cheikh Anta Diop, John Mbiti, Julius Nyerere and Kwasi Wiredu. Evidently, ethnophilosophy has a long list of adherents with each implying in its position its defining feature of African philosophy. None of them seem to match up with each other. Ethnophilosophy is a chameleon with assorted colours pending where it manifests. So Cheikh Anta Diop rejects Senghor's definition of the African as having the proclivity towards arts (not science and technology) while it stresses on the uniqueness of African culture. More than that Diop held that the African culture, as found in Egypt, was totally attuned to the development of science, mathematics, architecture and philosophy - the ground of classical Greek civilization. Mbiti argued for the unique structure of African 
culture in terms of personhood, causality (supernatural) and the nature of time. In Marcel Griaule's conversation with the Dogon priest of Ogotommeli and Odera Oruka's interview with his father and other Luo elders we find these elders as sages comparable to Thales and Socrates. ${ }^{9}$

From the above explorations, we find the definition of African philosophy as centred on factors responsible for the uniqueness of Africans as explanatory of their contribution to world civilization. Diop claims that Africans are matriarchal as against the patriarchal structure of the Europeans - these differences should be manifest in the political organization of both. While there have been lots of criticisms directed against most of these postures, from the theorists themselves and from outsiders, we may note a few of them: First, defining African philosophy in terms of sages raises the problem that the difference between a non-African anthropology/ethnology and African philosophy lies in the nationality of the researcher (not in the defining elements of philosophy such as logic, epistemology and metaphysics).

Two, philosophy and the history of ideas is not necessarily the same thing. Philosophy demands the involvement of logic, epistemology and metaphysics, but the history of ideas needs not contain these elements - the history of ideas may be only an account of thoughts. Thus, the beliefs of the Akan and the Yoruba may always remain beliefs until they are shown as having the distinctive features of philosophy. Calling them philosophy may mean what is meant when someone says that 'my philosophy is live and let live'; it reminisces the music of Oliver de Coque, a Nigerian Highlife musician titled 'ibiri kam mbiri' that means 'live and let me live'. ${ }^{10}$ This aspiration of being considerate of your neighbour as one lives and executes his life's projects runs deep in Africa. It is a sense of responsible living and cohabitation and a reminder that we need each other in life.

Three, critics of ethnophilosophy would argue that focusing on the past as the root of authenticity detracts from a serious position that examines all practices in terms of their contribution to the 
liberation of Africa. For a reason like this, Hountoundji claims that Tempels' text was meant to placate Africans and assist European administrative targets. Though certain scholars have argued that philosophy is meant to reflect the particular view of a race, Appiah, in opposition, claims that African philosophy should not express the outlook of the African race. Truly speaking, 'race' is an illusion. As a concept, philosophy should reject it for it was established to favour the European. ${ }^{11}$

Fourth, in returning to excavate Africa's ancestral pasts, there is a tendency to lavish praise on the bundle of our ancestral cultural life as if everything about it was positive and growth-yielding. There were many things in those traditional systems and practices that were very inhumane and destructive; things that humiliated men and women, impoverished them and permanently debarred them from experiencing the joy of positive exploits that come from developing one's potentials and having them operational in solving societal problems. African Philosophy must strive to encourage positive and growth-driving values rather than lump these types of values together with those ones that debilitate and emasculate human beings.

\section{Universalism}

This is a philosophical view that is rooted in the idea of logic and rationality. It is a school of thought that holds that Africans engage themselves in philosophical reflections whey they are under the guidance of criticality and literacy. Those who are found with this vision are generally regarded as the logical positivists/neopositivists, the analytics and the rationalists. Advocates of this school will include: Kwasi Wiredu, Paulin Hountoundji, Peter Bodunrin and Kwame Gyekye.

Kwasi Wiredu argues that the development of philosophy in Africa parallels the development of philosophy in Europe and that we should not assume traditional African thought for a standard of African philosophy in the same way that traditional European thought is not equal or a model for European philosophy. Paulin 
Hountoundji is of the opinion that philosophy is critical literature and so African philosophy is critical literature written by Africans for Africans. Even at this point, the scholars are in disagreement. While Paulin Hountoundji and Kwasi Wiredu conceive literacy as necessary for the existence/practices of African philosophy, Odera sees active engagement in reflecting upon the assumptions of a cultural system as the sole prerequisite for philosophy. And this can occur without any invocation of literacy. Oruka puts the sages, in this line, on a par with Socrates. Hountoundji counters by stating the significance of Plato for the possibility of Socrates. ${ }^{12}$

Wiredu, Nkrumah, Nyerere, Kaunda, Sekou Toure among other thinkers used philosophy for political reasons. But post-colonial philosophers are professional philosophers, who have background training in Western philosophy. While some condemn these professionals as traitors on the grounds of promoting the logic, epistemology and metaphysics characteristic of Western philosophy, Wiredu states that the job of these philosophers is to render the Western goods consumable by Africans. Though developed in the West, it could be made useful to us; this does not mean the concentration of energies upon foreign materials. Indigenous materials that are useful may be used as they can give great insight. Nevertheless, whether indigenous or not, the same 'criticality' should be of benefit to both indigenes and non-indigenes.

'Conceptual Decolonization' is what Wiredu thinks to be the critical function of post-colonial African philosophy. It involves avoiding or reversing the unquestioned acceptance of Western ideas by Africans. He believes that Africans have been forced to receive foreign conceptual schemes and categories through religion, language and politics. To solve this problem, we should start translating the 'conceptual projects and notions in Western terms' into indigenous language. If the resultant of this translation is meaningful (within the native language), then we may progress with further considerations. If not intelligible, then we may be faced with a pseudo-problem brought in by linguistic domination. It is within language (its categories and scheme included) that we project our 
concerns and problems. The difficulty with this solution lies in the multiplicity of language in Africa. In Nigeria, an example of a nation-state, to what extent can the linguistic uniqueness of one African language reflect that of the other language such as: Hausa, Yoruba, Ibibio, Tiv, etc.? How does this relate to Africans in the diaspora, who have, say, French, English, German as their lingua franca? Would Wiredu's recommendations be different from the ones given by ordinary language philosophy? Will it escape the flaws of ordinary language philosophy? ${ }^{13}$

Whatever may be the outcome, it would interest us to note that whether it is intelligible or not, the African language into which the translation is aimed at already contains in itself a stream of identities or values that may help us develop positively or not; the onus is on us to purge our lingua franca of the unproductive and enfeebling conceptions and values they carry. I am of the opinion that it is inconsequential whether it is translated into our lingua franca or not because anyone using the foreign language must, sooner or later, translate the matter into his or her local dialect for effective meaning and use.

The employment of rationality and logic by this group of scholars on African Philosophy is fatal, an exercise in nullity and a sheer waste of time, energy and resources. This is because the principles of rationality defined by logic make them inhumane, artificial, and totally removed from man's experience of knowing. It demands, like I have argued in some of my works, for example, that man's knowledge must never include emotions/passion, imagination, intuition, faith/belief, divine inspiration, ambiguity and irony, etc. Herein lies the crises of rationality in African Philosophy. I have argued in various places that man cannot know without the involvement of his emotions, faith/belief, imagination, etc.; that the only place you can find a knowledge that does not involve human emotions is artificial intelligence like computers and robots. ${ }^{14}$ Thus, any system of knowledge that must represent man's authentic mode of knowing, whether under the caption of rationality and logic or not, has to be a restructured knowledge-system. So, for African 
Philosophy, under universalism, to take as its starting point the faulty epistemic indices of Western Philosophy, it has decided to make a journey into irrelevance since the structure of its operation is not related to human beings but machines.

\section{Hermeneutics}

The approach to the marking off of African philosophy called the hermeneutical approach, would boast of personalities such as Theophilus Okere, Tsenay Serequeberhan, Okondo Okolo, Franz Fanon, Leonardo Harris, Lucius Outlaw and V. Y. Mudimbe as its exponents among others. According to these thinkers, the starting point of philosophy for most Africans is tied to real life experiences, which is built around a struggle for liberation from European hegemony whether cultural and/or economical. The hermeneuticists' target is the search for ways of achieving freedom from the harms/hurts caused by European imperialism. Traditional beliefs and oral discourses of Africans are only useful when it aids the attainment of this goal of liberation; outside this purpose, they have no usefulness. ${ }^{15}$ It is called hermeneutical because one of its chief exponents, Tsenay Serequeberhan took-off with Gadamer and Heidegger as his influential guides (Hans Gadamer and Martin and Heidegger are two Western scholars associated with Hermeneutics). Some people think that Theophilus Okere initiated this school. But the idea does not seem to have sailed through the congregation of thinkers.

Tsenay Serequeberhan, in his capital text, The Hermeneutics of African Philosophy argued that the problem concerns the major issue of the post-colonial dilemma. The problem revolves around the tension between the ongoing control of Africa by Europe in the guise of neo-colonial puppets and the ongoing influence of precolonial traditions as found in rural environments. Africans need to assert themselves as subjects rather than as mere objects in the transformation of man in history. ${ }^{16}$ In criticizing the preceding theoretical proposals, Serequeberhan accuses the professional philosophers and ethnophilosophers of replicating the visions of 
Europe about Africa. How? Ethnophilosophers like Senghor and Tempels accepted and considered as positive the classification of racial distinction used by Europeans to define Africans as inferior to the Europeans. Professional philosophers like Nkrumah and Hountoundji used one colonial model to replace another - a capitalist yoke' replaced by a communist yoke'. ${ }^{17}$

The appropriate solution to the European violent conquest of Africa should be replaced by way of a violent expulsion of European control, for example, as found in neo-colonial puppets of Europe. "The possibility of African freedom is concretized..." in the function of the talents of westernized Africans with the non-westernized members of rural Africa. In this way, Africans would 'return to the source', the true ground of African freedom. It is here that exploitation would fizzle out because the westernized Africans would invest their knowledge by the assistance they rendered to the rural dwellers; this is a hybrid state. At this point, fossilized, unexamined traditions of the past and of the colonizer are thrown out - this is the dance of serious critique. The strengths and weaknesses are opened and held up for robust evaluation. The resultant effect would be nothing, but a modern African, who can act, exert himself rather than a being to be merely acted upon. ${ }^{19}$ It is here that Serequeberhan's "return to the sources" and Wiredu's "conceptual decolonization" seem to beat at an equal pulse rate. To my mind, what we need is not any kind of violence esp. physical violence like Franz Fanon's writings tend to suggest. We need cultural violence, a kind of violence that encourages Africans to believe that they can be creative; that the problem is not necessarily the outsiders but ourselves. You can only be defeated when you are not skilful enough to handle the challenge before you. Slavery succeeded because we were not intellectually and communally organized to handle such an incursion; our own people aided and abetted it. Why did we fail to keep them off our shores? Japan defeated the westerners the first time they tried to enter their land even though they were overpowered during the second attempt of the westerners. There is no account in known history that our people did put up any attempt 
at keeping them out of our shores. Why did our own people connive in selling their own brothers and sisters? As long as there is darkness (spiritual, intellectual, moral, imaginative, etc.) in the heart of men, they cannot avoid the stranglehold of a people, who are (more) organized and enlightened.

\section{The Equalization Scheme}

The preceding classifications of thoughts do not capture every trend in African philosophy. There are other manifestations of African Philosophy. This writer opines that there is another movement that is very unique and distinct because of what it fundamentally thinks is the purpose and meaning of African philosophy; it is the equalization scheme. The equalization scheme in African philosophy is my coinage. Informed by the idea that Europeans do not think that Africans have any philosophy, this scheme sets out to demonstrate that Africans have a philosophy (ies) that can be said to stand on a par with the submissions of Western philosophers.

The proponents of this scheme think that we are equal to the West because the conceptions they have such as: universality, supreme being and/or ultimacy, death, eternal return of the same, truth as correspondence, middle term, predestination, temporality, atemporality, etc. are also present in the labyrinth of African thoughts. Their mission involves bringing forth materials from traditional African cultural systems such as myths, folktales, social organizations, oracular utterances, proverbs, artefacts, etc. that either connote or denote some conceptions in Western philosophy. Once they have done that, it is their thinking that they have shown the possession of philosophy by Africans and these they have done by trying to display points of equalization of African conceptions with Western philosophical conceptions. Some thinkers who may be said fit into this receptacle include Francis $\mathrm{Njoku}^{19}$, B. E. Nwigwe ${ }^{20}$, Bartholomew Abanuka ${ }^{21}$, C. B. Nze ${ }^{22}$, Augustine $\mathrm{Obi}^{23}$, Matthew Chukwuelobe $^{24}$, Egbeke Aja ${ }^{25}$, etc. Whether they succeeded or not in their pursuit, one point is that they revealed, by implication, that before their writings, Africans seem not to have had any formal 
philosophical system like the Europeans; they did this when they began deducing ideas and concepts from the emblems of their ancestral past - proverbs, myths, folktales, proverbs, riddles, artefacts etc. and juxtaposing them with the philosophical systems of the West. Before the emergence of a barrage of these materials, focusing on the possible philosophical import of traditional African world occasioned by the perceived challenge posed by Western thinkers, this type of exercise seem not have existed. They subtly fell into the very ditch they seem to have been running away - from subjugation to Western intellectual domination. How? In their attempt to move away from a sense of the domination of their minds by Western ideological project, they went about trying to force interpretations out of African symbols to showcase concepts in African worldviews that matched what existed in Western scholarship. Thus, their pursuit was guided by the very intellectual stream they were avoiding. African philosophy is, for these scholars, a philosophical reflection that aims at showcasing the possession, by Africans, of concepts found in Western philosophy having African traditional ancestry as its reference point.

\section{Summary and Conclusion}

In the exercise of the Great Debate, within which the problem of the definition of African philosophy arose, one thing must always be noted: the debate would not have arisen if the question of Hart was well understood as not a doubt of the African's capacity and capability for philosophy and the existence of African philosophy.

Sequel to this is the fact that most people, who argued against the existence of African philosophy failed to recognize that there exists different strands of thoughts in African philosophy. Debating over traditional African emblems eclipsed the other aspects of African philosophy and brought forth different thought-lines such as universalism, hermeneutics and according to my analyses, the equalization scheme in African philosophy even though discourses on the existence of African philosophy seems to have quietened for some time. Until African Philosophy turns unto confronting issues 
influencing present-day African societies and its impact on the development of her people and the redemption of her image as a dignified race by engaging the challenges of the empirical sciences, globalization, Information and Communication Technology, imperialist influenced educational curricula in our tertiary institutions, etc., it may not transform itself into an effective machinery for the movement of Africa into this age of competitive intelligence. 


\section{References}

1. J. Oguejiofor \& Godffrey I. Onah, eds., African Philosophy and the Hermeneutics of Culture: Essays in Honour of Theophilus Okere (Munster: Lit Verlag, 2005), x.

2. T. U. Nwala, "The Otonti Nduka Mandate: From Tradition to Modernity", an Inaugural Lecture of the University of Nigeria, Nsukka, March 15, 2007, 3.

3. T. U. Nwala, "Summary Discourse on the Debate Concerning the Existence, Nature and Scope of African philosophy" (1970 90): In Critical Review of the Great Debate on African Philosophy 1970 - 1990 (Enugu: Hillys Press 1992), 19.

4. Ibid, 18.

5. The arguments are clearly exemplified by T. U. Nwala and Albert Mosley; 'Schools of Thought in African Philosophy: A Critical Review' in Uche, Vol.10, 2004, 1-13 and Albert Mosley, ed., African Philosophy: Selected Reading, (Englewood Cliffs, NJ: Prentice Hall, 1995).

6. Samuel Imbo, An Introduction to African Philosophy (NY: Rowman \& Littlefield, 1998); P. H. Coetzee and A. P. J. Roux (eds.) The African Philosophy Reading (NY: Routledge, 1998).

7. Albert Mosley, "African Philosophy at the Turn of the Century: Ethnophilosophy

Revisited" http://www.smith.edu/philosophy/african.html. Date accessed: December 04, 2010.

8. Ibid.

9. Ibid.

10. See "African (http://users.ox.ac.uk/ shil0124/african-philosophy.html). Accessed December 04, 2004. Cf. The Second Track, "Ana Enwe Obodo Enwe" in the Album titled "Oliver de Coque and his Expo Ogene Sound Super of Africa. Classic Hits” by Panovo Entertainments.

11. See Albert Mosley, "Are Racial Categories Racist" in Research in African Literatures, 28. 4 (Winter, 1997), 101 - 111. 
12. Paulin Hountoundji, African Philosophy: Myth and Reality (Bloomington: Indiana University Press, 1983), 106.

13. "African Philosophy at the Turn of the Century: Ethnophilosophy Revisited".

14. Emmanuel J. Ibuot, "Traditional African Ideology and the Challenges of Development in Nigeria,", The Constitution, Vol. $10,2010,58-59$.

15. Ibid, 4.

16. Ibid.

17. Tsenay Serequeberhan, The Hermeneutics of African Philosophy (New York: Routledge, 1994), 42. In the references of African Philosophy at the Turn of the Century: Ethnophilosophy Revisited" (p.10), we can possibly perceive Wiredu establishing an African model of ordinary language philosophy in the place of an Anglo-American form of it.

18. "African Philosophy at the Turn of the Century: Ethnophilosophy Revisited".

19. Francis O.C. Njoku, Essays in African Philosophy, Thought \& Theology (Owerri: Claretian Institute of Philosophy, 2002), 127 $-141$.

20. B. E. Nwigwe, "Causality in Selected Igbo Cultural Novels: Perspectives in Igbo Metaphysics," West African Journal of Philosophical Studies, Vol. 7, December 2004, 2 - 26.

21. B. Abanuka, "Philosophy and the Igbo World: A Revisitation," Uche, Vol. 13, 2007, 63 - 75.

22. C. B. Nze, "Igbo Concept of Truth as Correspondence," Uche, Vol. 9, 1994, 1 - 8.

23. Augustine Obi, "Implications of Ino Uwa for Philosophy," Uche, Vol. 10, 2004, 53 - 59.

24. Matthew Chukwuelobe, "Igbos and the Sense of Finitude," Uche, Vol. 14, 2008, 77 - 82.

25. Egbeke Aja, Metaphysics: An Introduction (Enugu: Donze Press, 2001), $72-81$. 